\title{
PENAKSIRAN KESENJANGAN OUTPUT INDONESIA: APLIKASI METODE KALMAN FILTER DAN HODRICK-PRESCOTT FILTER
}

\author{
Teguh Hadi Priyono \\ Fakultas Ekonomi Universitas Negeri Jember
}

\begin{abstract}
ABSTRAKSI
This research will measure the potential output in Indonesia using Kalman-filter and Hodrick-Prescott Filter. The model will observe the variations of output gap and inflation in Indonesia. The model of Kalman Filter shows a long-term trend of output nearly to actual output than the other model, however it shows a slow response than Hodrick-Prescott Filter.
\end{abstract}

Keywords: Output Gap, Inflation, Kalman filter and Hodrick-Prescote Filter.

\section{A. LATAR BELAKANG}

Kesenjangan output (output gap) merupakan variabel penting dalam kebijakan terutama dalam memprediksi tingkat inflasi. Kesenjangan output didefinisikan sebagai prosentase selisih antara output aktual dengan output potensial dimana output potensial adalah tingkat output yang konsisten dengan stabilitas inflasi. Pola hubungan antara kesenjangan output terhadap inflasi merupakan faktor penting terutama dalam manajemen permintaan (demand management) dalam mempengaruhi pergerakan output aktual. Hal ini disebabkan kesenjangan output menunjukkan derajat keketatan (tightness) dan kelonggaran (slackness) dari permintaan dan penawaran agregat. Indikator inilah yang digunakan untuk menilai tekanan terhadap perubahan harga (Bank of Japan, 2003).

Secara umum terdapat dua pendekatan utama dalam menaksir output potensial. Pertama, metode univariat yang mengidentifikasi output potensial berdasarkan perilaku masa lalu dari output tanpa memperhatikan pada variabel-variabel ekonomi. Pendekatan kedua, merupakan metode multivariat yang memperhitungkan perkembangan variabel-variabel makro lain sehingga memungkinkan adanya keterkaitan antara variabel berdasarkan teori ekonomi (Solikin, 2003). Kedua pendekatan yaitu univariat dan multivariat filter mengasumsikan bahwa trend dari komponen output dikarakteristikkan bersifat random walk, asumsi ini sangat sulit terutama jika dikaitkan dengan komponen output yang permanen akibat shok teknologi. Komponen output permanen (penawaran atau stochastic trend) diinterpretasikan sebagai suatu perubahan produktivitas dan dalam kerangka kerja fungsi produksi standar, asumsi output potensial yang random walk menunjukkan faktor produktivitas juga mengikuti random walk. Jika komponen output permanen diasumsikan random walk padahal kenyataannya tidak demikian, maka hal ini akan menyebabkan pengambil kebijakan akan membuat inferensi yang salah tentang kesenjangan output dan mempengaruhi tekanan terhadap inflasi (Claus, 1999).

Paper ini bertujuan untuk menaksir output potensial dengan menggunakan metode univariat mencakup Kalman Filter dan Hodrick-Prescott Filter. Terdapat empat pertimbangan utama pemakaian metode univariat yaitu: 1) dalam tataran teknis, metode univariat memiliki kesederhanaan konsep dibandingkan metode multivariat. Metode univariat menghindari permasalahan penggunaan restriksi/ identifikasi; 2) Pada dasarnya perkembangan output potensial mencerminkan perubahan fundamental ekonomi sehingga pengamatan terhadap karakteristik dasar kedua variabel cukup feasible; 3) tujuan 
penaksiran output gap adalah untuk mendapatkan suatu variabel yang dapat difungsikan sebagai variabel bebas yang dapat digunakan secara fleksibel dalam beragam model dengan atau tanpa restriksi.

\section{B. KAJIAN TEORITIS}

\section{Output Potensial dan Kesenjangan Output}

Berdasarkan dikotomi klasik, variabel riil bersifat independen terhadap variabel nominal. Dikotomi tersebut sangat penting dalam menjelaskan fluktuasi perekonomian dalam jangka panjang. Dalam jangka pendek, fluktuasi perekonomian lebih dipengaruhi oleh variabel-variabel nominal. Salah satu indikator yang membedakan antara jangka pendek dan jangka panjang adalah perubahan tingkat harga. Dalam jangka pendek, tingkat harga sukar untuk berubah seketika dalam merespon perubahan permintaan dan penawaran. Sedangkan dalam jangka panjang, tingkat harga akan selalu berubah untuk menyesuaikan permintaan dan penawaran. pendek:

Berikut ini adalah skema kesenjangan output yang dihasilkan dari fluktuasi output jangka

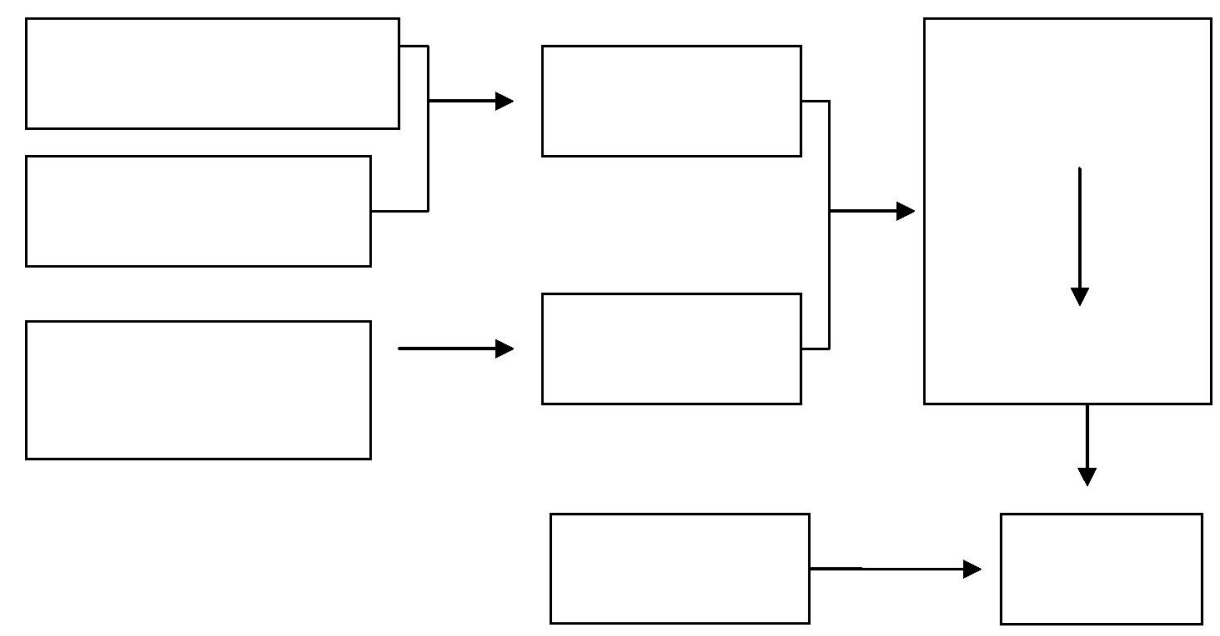

\section{Gambar 1. Diagram Kesenjangan Output}

Pada pasar barang, permintaan dibedakan secara sektoral menjadi C (konsumsi) yang merupakan fungsi dari disposible income $\left(\mathrm{Y}_{\mathrm{d}}=\mathrm{Y}-\mathrm{T}\right)$ dimana $\mathrm{T}$ adalah pajak, I (investasi) yang dipengaruhi oleh suku bunga (r) dan pengeluaran pemerintah $(\mathrm{G})$. Sedangkan pasar uang merupakan keseimbangan penawaran uang oleh bank sentral menjadi stok uang riil (M/P) dimana $P$ tingkat harga dan permintaan uang untuk transaksi yang dipengaruhi oleh pendapatan $(\mathrm{Y})$ dan untuk spekulasi yang dipengaruhi oleh suku bunga r. Pasar tenaga kerja terdiri dari permintaan tenaga kerja $\left(\mathrm{L}^{\mathrm{D}}\right)$ dengan upah riil $(w)$ dan penawaran tenaga kerja $\left(\mathrm{L}^{\mathrm{S}}\right)$ yang dipengaruhi oleh upah yang ditawarkan dunia usaha.

Berdasarkan skema tersebut, kesenjangan output dihasilkan dari fluktuasi jangka pendek dimana penawaran agregat dianggap tetap. Kesenjangan output juga menunjukkan tekanan dari luar negeri melalui nilai tukar dan atau suku bunga internasional. Syok yang terjadi pada sisi permintaan menyebabkan terjadinya fluktuasi jangka pendek, tidak dalam jangka panjang. Sedangkan syok pada sisi penawaran yaitu yang berasal dari pasar tenaga kerja berupa perubahan produktifitas, tingkat upah, jaminan sosial, harga energi (minyak), teknologi dan institusional.

Kesenjangan output dapat didefinisikan sebagai selisih antara tingkat output aktual dengan kecenderungan jangka panjang (trend) atau output potensial. Output aktual merupakan permintaan agregat (aggregate demand) sedangkan output potensial dikatakan sebagai penawaran agregat 


\section{Journal of Indonesian Applied Economics \\ Vol. 2 No.1 Mei 2008, 90-101}

(aggregate supply). Penawaran agregat bersifat tak teramati secara langsung. Kesenjangan output dapat diformulasikan sebagai berikut:

Output aktual - Output potensial

Kesenjangan Output $=$

Output Potensial

$x 100$

Output potensial merupakan tingkat output yang dihasilkan tanpa adanya sifat ketegaran harga dan friksi-friksi lainnya. Penentu tingkat output dapat bersumber dari kebijakan moneter, dan akan berubah-ubah sesuai dengan syok riil pada perekonomian. Sehingga output potensial berbeda dengan trend murni (pure trend) dari output aktual.

\section{Kesenjangan Output dan Inflasi}

Hubungan antara inflasi dan output dapat dijelaskan dengan menggunakan analisa kurva Phillip. Hasil studi A.W Phillip tahun 1958 menemukan adanya hubungan terbalik (inverse relationship) antara tingkat pengangguran dan perubahan tingkat upah di Inggris (Mankiw, 2003:361). Kurva Phillip menunjukkan respon upah nominal terhadap ketidakseimbangan pasar tenaga kerja (tingkat pengangguran). Dalam kondisi dimana tidak terjadi ketidakseimbangan, upah nominal akan meningkat karena adanya peningkatan produktivitas tenaga kerja, serta untuk mengimbangi pengaruh peningkatan harga terhadap tingkat perubahan upah riil. Pola penyesuaian tersebut dirumuskan dalam persamaan berikut :

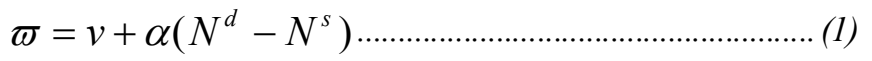

dimana, $\omega$ adalah perubahan upah nominal, $v$ adalah parameter yang mencerminkan implikasi adanya respon yang tidak simetris dari perubahan upah terhadap kelebihan penawaran atau permintaan di pasar tenaga kerja dan $\alpha$ adalah parameter dengan nilai positif. Jika terjadi kelebihan penawaran yang didistribusikan secara proporsional maka kelebihan penawaran atau permintaan sama di semua pasar yaitu $\mathrm{v}=0$. Sedangkan $\mathrm{N}^{\mathrm{d}}$ dan $\mathrm{N}^{\mathrm{s}}$ adalah permintaan dan penawaran tenaga kerja dimana $\mathrm{N}^{\mathrm{d}}=\mathrm{N}^{\mathrm{s}}$ adalah kondisi keseimbangan, sedangkan bila $\mathrm{N}^{\mathrm{d}}$ ““ $\mathrm{N}^{\mathrm{s}}$ berada dalam ketidakseimbangan. Sehingga persamaan (1) dapat dirumuskan dalam bentuk:

$\varpi=v+g(u)$

dimana, $g(u)$ fungsi dari u yang menggambarkan kondisi terjadinya kelebihan permintaan di pasar tenaga kerja dan dapat diwakili dengan perbedaan antara pengangguran pada full employment dan pengangguran aktual $\left(\mathrm{u}_{\mathrm{f}}-\mathrm{u}\right)$. Sehingga dapat dituliskan:

$\varpi=v+\beta\left(u_{f}-u\right)$.

Untuk mencapai kestabilan upah, maka dengan menetapkan $\omega=0$ dan u dapat dihitung sebagai berikut :

$u^{*}=u_{f}+v / \beta$

$\mathrm{u}^{*}$ adalah tingkat pengangguran yang tidak mendorong inflasi, sehingga kurva Phillip dapat dituliskan sebagai:

$\pi=\varpi-\rho$

dimana, $\rho$ adalah tingkat produktivitas tenaga kerja. Jika diasumsikan $\rho=0$ maka didapatkan kurva Phillip sebagai berikut:

$\pi=\beta\left(u^{*}-u\right)$

Pola hubungan dalam kurva Phillip menunjukkan kombinasi hubungan antara tingkat pengangguran dan inflasi pada suatu periode waktu yang mempunyai tendensi menurun (downward sloping).

Dalam perkembangannya, sesuai dengan karakteristik siklus kegiatan usaha yang mengidentifikasi keterkaitan yang erat hubungan negatif antara pola pengangguran dan pertumbuhan 


\section{Penaksiran Kesenjangan Output Indonesia}

Priono

output riil yang kemudian dikenal dengan hukum Okun, kurva Phillip dapat diturunkan dari pola hubungan antara tingkat inflasi dan pertumbuhan output riil. Kecenderungan pola hubungan yang terjadi adalah meningkat dimana peningkatan inflasi sejalan dengan peningkatan output riil. Pola hubungan ini dikenal sebagai kurva penawaran jangka pendek. Spesifikasi umum dari kurva Phillip berdasarkan pola hubungan tersebut adalah:

$$
\pi=\delta\left(y-y^{*}\right)
$$

dimana, y dan $y^{*}$ masing-masing adalah pertumbuhan output riil aktual dan potensial dan $\delta$ adalah parameter dengan nilai positif.

Dengan memperhitungkan adanya tenggang waktu dari pengaruh suatu variabel, serta bentuk persamaan yang diperluas (augmented version) maka didapatkan persamaan struktural kurva Phillip sebagai berikut:

$$
\pi_{t}=\sum_{i} \theta_{i} \pi_{t i}+\delta \hat{y}_{t i}+\varepsilon_{t}
$$

dimana, $\pi_{\mathrm{t}}$ dan $\pi_{\mathrm{ti}}$ masing-masing adalah inflasi periode saat ini dan sebelumnya, $\mathrm{w}_{\mathrm{ti}}$ adalah pertumbuhan output riil atau deviasi output riil terhadap tingkat potensialnya pada periode lalu, dan $\varepsilon_{\mathrm{t}}$ adalah random disturbance.

\section{METODE PENELITIAN DANANALISIS DATA}

\section{Metode Penaksiran Output Potensial:}

\section{a. Hodrick-Prescott Filter}

Metode ini digunakan untuk memperoleh taksiran komponen trend jangka panjang. Secara teknis metode ini merupakan filter linier dua sisi (backward-forward) yang digunakan untuk menghitung smoothed-trend series (s) dari output (y) dengan cara meminimumkan loss function (L) yaitu varians y di sekitar nilai s dengan penalti tertentu.

$$
\begin{gathered}
y_{t}=s_{t}+c_{t} \\
\min L=\sum_{t=1}^{T}\left(y_{t}-s_{t}\right)^{2}+\lambda \sum_{t=2}^{T-1}\left[\left(s_{t+1}-s_{t}\right)-\left(s_{t}-s_{t-1}\right)\right]
\end{gathered}
$$

Parameter penalti $\lambda$ mengontrol kemulusan series $\mathrm{s}_{\mathrm{t}}$, semakin besar nilai semakin mulus perkembangan $\mathrm{s}_{\mathrm{t}}$. Apabila mencapai nilai tak terhingga $\mathrm{s}_{\mathrm{t}}$ mendekati pola trend linier. Hodrick dan Prescott merekomendasikan $\lambda=1600$ untuk data kuartalan dan $\lambda=100$ untuk data tahunan.

\section{b. Kalman Filter}

Metode Kalman Filter dikembangkan pertama kali oleh R.E Kalman (1960) dan Kalman dan Bucy

(1961). Metode ini merupakan alat analisis untuk mengestimasi secara recursive sebuah state $z_{t}$ dari observasi variabel output $y_{1}, \ldots \ldots . ., y_{T}$ dengan meminimumkan mean of squared error. Metode ini memiliki kekuatan dalam beberapa aspek yaitu mendukung estimasi dalam state yang lalu, saat ini dan yang akan datang, disamping itu metode ini dapat digunakan pada saat sistem permodelan asal tidak diketahui.

Kalman Filter merupakan algoritma pengolahan data rekursif optimal. Satu aspek optimalitas ini adalah bahwa Kalman Filter menghubungkan seluruh informasi yang bisa diberikan padanya. Kalman Filter mengolah semua pengukuran yang ada, dengan menggunakan: (1) pengetahuan sistem dan dinamika alat pengukuran, (2) gambaran stastistik gangguan sistem, kesalahan pengukuran, dan ketidak-pastian model, serta (3) informasi apapun yang ada mengenai kondisi awal dari variabel yang berkepentingan. Sebagai contoh, untuk menentukan kecepatan pesawat, bisa digunakan radar Doppler, atau indikasi kecepatan sistem navigasi inersial, atau pitot dan tekanan statis serta informasi angin 
relatif dalam sistem data udara. Kalman Filter bisa dibangun untuk menggabungkan seluruh data dan pengetahuan mengenai beragam dinamika sistem ini untuk menghasilkan perhitungan terbaik keseluruhan atas kecepatan.

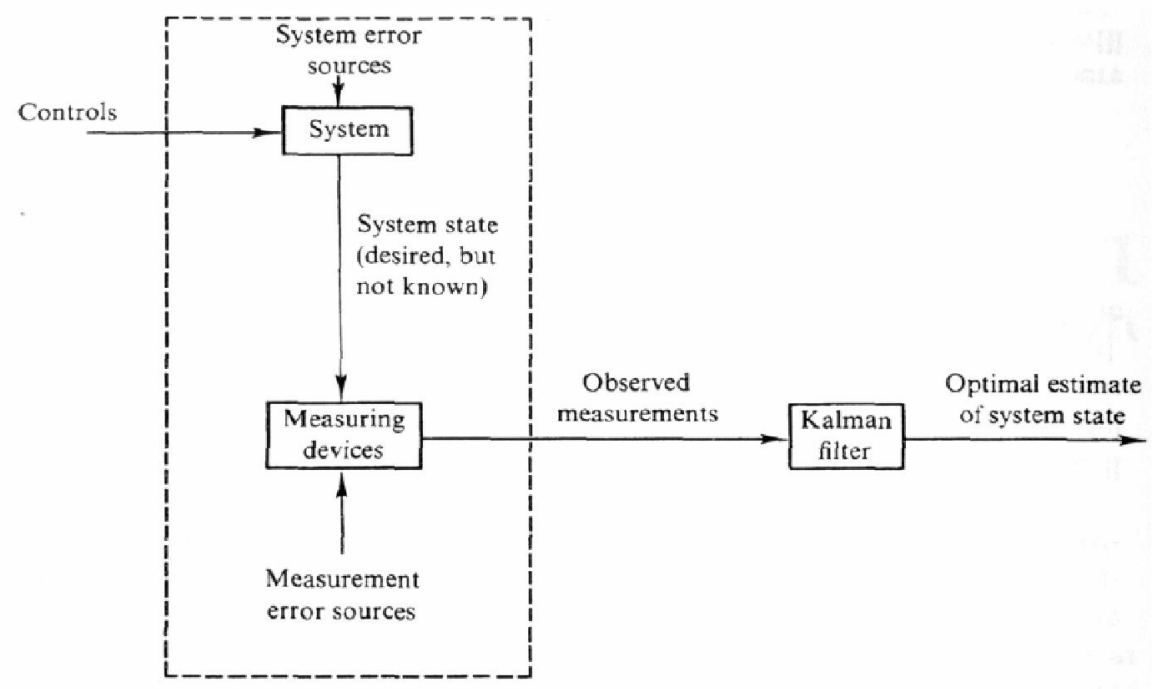

Gambar 2. Typical Kalman Filter Application

Gambar 2 menunjukkan situasi tipikal dimana Kalman Filter bisa digunakan sesuai kelebihannya. Sebuah sistem dalam bentuk tertentu dikendalikan oleh kontrol yang diketahui, dan alat pengukuran memberikan nilai kuantitas tertentu yang sesuai. Pengetahuan atas input dan output sistem ini adalah semuanya yang secara eksplisit muncul dari sistem fisika untuk tujuan perhitungan.

Pentingnya filter sekarang menjadi jelas. Biasanya variabel kepentingan, beberapa angka kuantitas tertentu untuk menggambarkan "keadaan" sistem, tidak bisa diukur secara langsung, dan beberapa alat penghitungan nilai-nilai ini dari data yang ada harus dihasilkan. Kalman Filter menggabungkan seluruh data pengukuran yang ada, ditambah pengetahuan terdahulu mengenai sistem dan alat pengukuran, untuk menghasilkan perhitungan variabel yang diinginkan, sehingga kesalahan diminimalisir secara statistik. Dengan kata lain, jika kita akan melakukan penyaringan kandidat berulang kali untuk penerapan yang sama, maka hasil rata-rata dari Kalman Filter akan lebih baik dari hasil rata-rata yang lainnya.

Dengan menggunakan asumsi normalitas, estimator dari sebuah state mengikuti conditional expectation $E\left(z_{t} \mid y_{1}, \ldots ., y_{t}\right)$ dan conditional covariance matrix $\operatorname{cov}\left(z_{t} \mid y_{1}, \ldots ., y_{t}\right)$ untuk mengukur estimasi atau prediksi ketidakpastian. Untuk $t>T$, estimator $E\left(z_{t} \mid y_{1}, \ldots ., y_{T}\right)$ adalah prediksi pada $\mathrm{T}$ asal. Perhitungan, $\mathrm{t}=1, \ldots ., \mathrm{T}$ disebut dengan filtering untuk membedakan dari permasalahan forecasting.

\section{c. Metode Penaksiran Output Gap}

Output gap didefinisikan sebagai detrended output aktual yang diukur secara empiris dengan menggunakan residual dari hasil regresi output aktual terhadap output potensial. Sedangkan output potensial dihitung dengan menggunakan metode Hodrick-Prescott filter dan Kalman Filter. 


\section{Penaksiran Kesenjangan Output Indonesia}

Priono

\section{d. Hubungan Kesenjangan Output dan Inflasi}

Hubungan atau pengaruh kesenjangan output terhadap inflasi adalah dapat lihat dari pengujian model kesenjangan yang dikembangkan oleh Coe dan McDermott (1997) sebagai berikut:

$$
\Delta \pi_{t}=\alpha_{1}+\sum_{k=0}^{\rho} \beta_{1 k} \Delta G A P_{t-k}+\varepsilon_{2 t}
$$

Persamaan model tersebut terkait dengan perubahan inflasi terhadap perubahan kesenjangan output dimana kesenjangan output yang positif (negatif) akan meningkatkan (mengurangi) inflasi yang berarti jumlah $\beta_{\mathrm{i}}$ adalah positif dan signifikan (Claus,2000). Model Coe dan McDermott tersebut diturunkan dari model kurva Phillips expectation-augmented dengan adaptive expectation sebagai berikut : $\quad \pi_{t}=\alpha+\pi_{t}^{e}+\sum_{i=0}^{p} \beta_{i} Y_{G A P t-1}+\varepsilon_{t}$

dimana $\alpha$ adalah konstanta, $\pi_{t}$ adalah tingkat inflasi saat ini, adalah ekspektasi inflasi, $Y_{g a p}$ adalah kesenjangan output dan $\varepsilon_{t}$ adalah variabel random.

\section{e. Prediksi Inflasi}

Output gap sangat penting dalam menjelaskan pergerakan dan prediksi inflasi. Untuk keperluan prediksi dapat digunakan model vector autoregression (VAR). VAR merupakan model atheoritic dimana tiap variabel diregressikan dengan lag dirinya sendiri dan variabel lain dalam sistem. Berikut reduced form model VAR:

$$
X_{i t}=\Phi(L) X_{i t-1}+\varepsilon_{i t}
$$

Dimana, adalah covariance stationary vector process yaitu inflasi dan output gap; adalah vector of random disturbance; dan adalah polynomial lag operator.

Fungsi impulse response dan variance decomposition merupakan properti dari model VECM/VAR untuk melihat dampak goncangan dari variabel inovasi terhadap variabel-variabel lainnya. Impulse response adalah respon variabel endogen akibat adanya inovasi (kejutan) dari variabel endogen yang lain. Variance decomposition bertujuan untuk memisahkan dampak masing-masing variabel inovasi tersebut secara individual terhadap respon yang diterima suatu variabel. Analisis impulse response mempunyai kemampuan forward looking sehingga berguna untuk melacak atau memprediksi nilai sekarang dan yang akan datang dari variabel endogen akibat adanya efek kejutan atau inovasi atas variabel yang bersangkutan. Impulse response merupakan suatu alur (path) dimana variabel akan kembali pada keseimbangan setelah mengalami kejutan.

\section{HASIL PENELITIANDAN PEMBAHASAN}

\section{Penaksiran Output Potensial dan Output Gap}

Fluktuasi ekonomi makro membedakan antara fluktuasi jangka pendek yang bersifat siklikal dan perkembangan jangka panjang yang mencerminkan perilaku dasar dari output. Output gap merupakan perbedaan antara level aktual dari output dengan kecenderungan jangka panjang (trend) atau tingkat potensialnya. Untuk melakukan penaksiran output potensial secara akurat sulit dilakukan, dan tidak ada prosedur baku yang digunakan untuk menaksir output potensial. Penaksiran output potensial dilakukan dengan menggunakan perbandingan dua metode yaitu Hodrick-Prescott filter dan Kalman filter. Perbandingan hasil kedua metode tersebut dapat dilihat dari gambar berikut. 


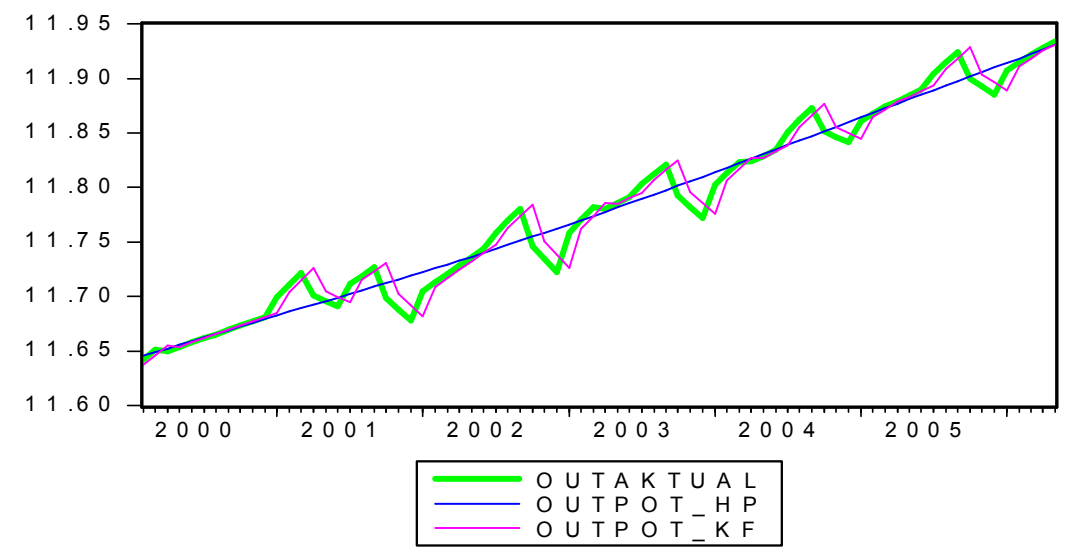

\section{Gambar 3. GDP Aktual, Trend Kalman Filter dan Trend HP}

Berdasarkan gambar terlihat bahwa trend jangka panjang output yang mendekati pergerakan output aktual adalah dengan metode Kalman Filter dibandingkan dengan Hodrick-Prescott filter. Metode kalman filter merupakan metode yang cukup powerful terutama dalam mengestimasi state dari periode masa lalu, saat ini dan yang akan datang.

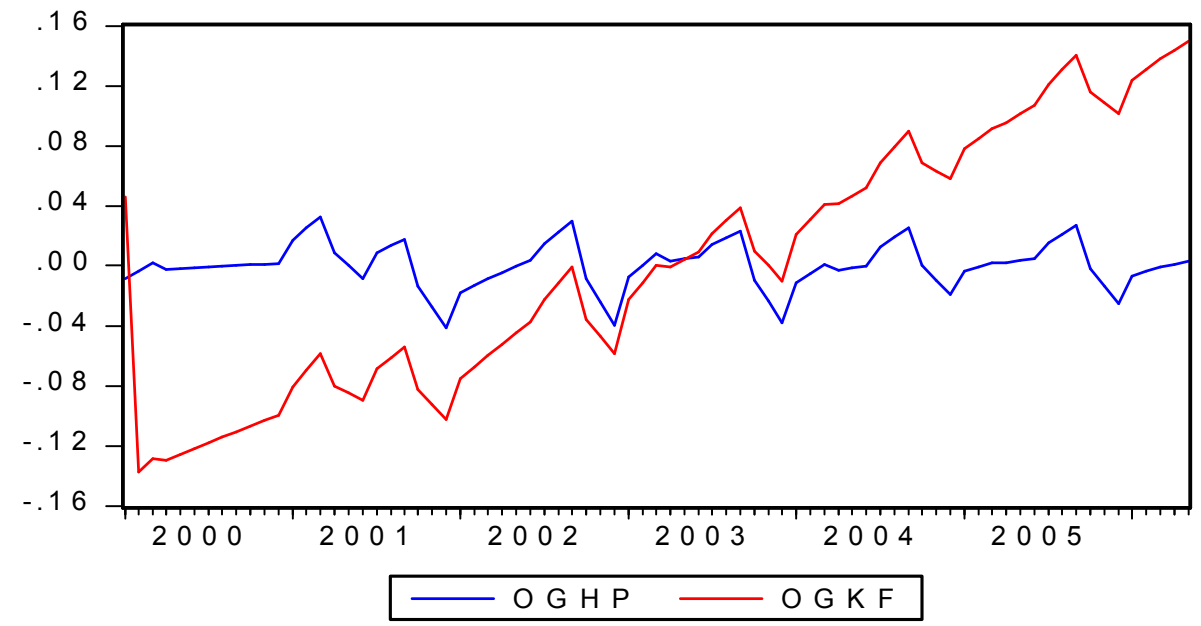

\section{Gambar 4. Output Gap model Hodrick-Prescott (OGHP) dan Kalman Filter (OGKF)}

\section{Penaksiran Model Vector Autoregression}

a. Pemilihan Panjang Lag Model VAR

Pemilihan panjang lag dilakukan dengan menggunakan kriteria informasi yaitu Schwarz Information Criterion. Penelitian ini menggunakan batas maksimal lag yang diperhitungkan adalah tujuh. 
Tabel 4. Pemilihan Order VAR

\begin{tabular}{ccc}
\hline Order & OGHP & OGKF \\
\hline 0 & -6.341406 & -5.452195 \\
1 & -11.82132 & -11.73342 \\
2 & $-11.84544^{*}$ & -11.67519 \\
3 & -11.74155 & -11.46072 \\
4 & -11.80874 & $-11.75765^{*}$ \\
5 & -11.72801 & -11.59427 \\
6 & -11.57161 & -11.36200 \\
7 & -11.37611 & -11.17234 \\
\hline
\end{tabular}

*) menunjukkan signifikansi pada $\alpha=5 \%$

Berdasarkan uji pemilihan panjang lag terlihat bahwa lag optimal untuk model VAR model OGHP terletak pada order dua, dan model OGKF adalah pada lag empat.

\section{b. Uji Kointegrasi}

Pendekatan Johansen reduced rank test dapat digunakan untuk menguji eksistensi dari hubungan kointegrasi. Jumlah keterkaitan vektor kointegrasi menunjukkan adanya jumlah hubungan jangka panjang dalam sistem dan untuk mendukung prediksi teori. Prosedur dalam uji kointegrasi Johansen menyarankan pentingnya joint hypotesis untuk menentukan ada tidaknya komponen deterministik (seperti intercept dan trend) dalam model maupun terhadap rank yang dikenal dengan Pantula principle (Harris, 1995:97). Pengujian dilakukan dari model yang paling restriktif dan membandingkan nilai trace statistic terhadap nilai kritisnya dan berhenti pada saat pertama hipotesis nol tidak ditolak. Hasil uji kointegrasi Johansen dapat dilihat pada lampiran.

c. Impulse Response dan Variance Decomposition

Analisa impulse response menggambarkan pengaruh adanya shock terhadap variabelvariabel endogen yang terdapat dalam model dan untuk melihat keterkaitan dinamis antar variabel dalam model yang mengacu pada kondisi ortogonalitas. Dalam hal ini dilihat bagaimana keterkaitan antara variabel-variabel yaitu output gap baik dengan metode Hodrick-Prescott (OGHP) maupun Kalman filter (OGKF) dengan tingkat inflasi.

Gambar berikut menunjukkan adanya shocks output gap dengan metode Hodrick-Prescott di Indonesia memberikan efek permanen yang positif terhadap perkembangan inflasi terutama setelah kuartal ke-3. Pada awal kuartal, pengaruh output gap memberikan pengaruh yang negatif terhadap inflasi dan berlangsung hingga kuartal ke-3. 
R e sponse to Cholesky One S.D. Innovations \pm 2 S.E.

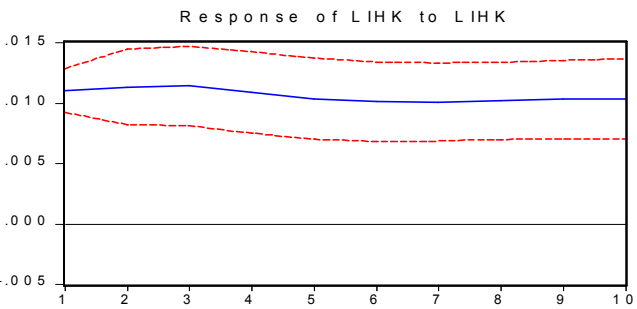

Response of LIHK to OGHP
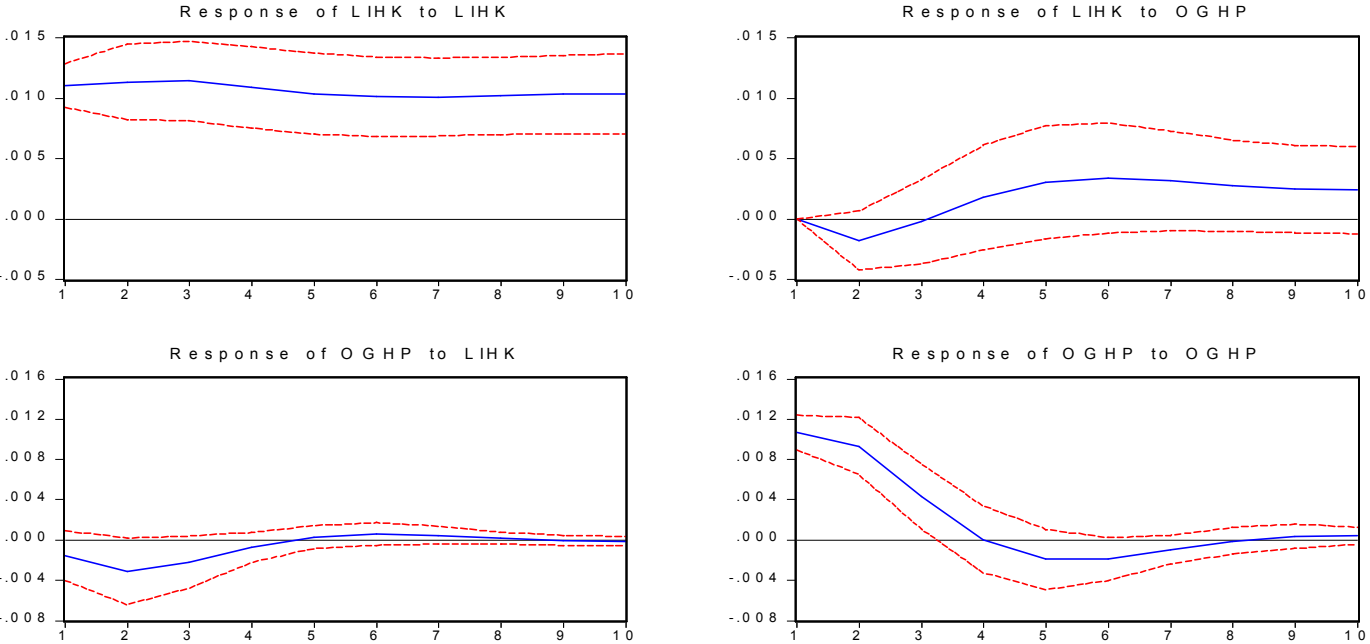

\section{Gambar 5. Respon Inflasi terhadap shock Output Gap (OGHP)}

Sedangkan respon inflasi terhadap shocks output gap dengan metode Kalman Filter di Indonesia menunjukkan pola yang hampir sama dengan metode Hodrick-Prescott yaitu memberikan efek permanen yang positif terhadap perkembangan inflasi terutama setelah kuartal ke-3 mendekati kuartal ke-4. Pada awal kuartal, pengaruh output gap memberikan pengaruh yang negatif terhadap inflasi dan berlangsung hingga kuartal ke-3. Perbedaan dari keduanya adalah metode Kalman Filter, adanya shocks output gap cenderung direspon lebih lambat oleh tingkat inflasi.
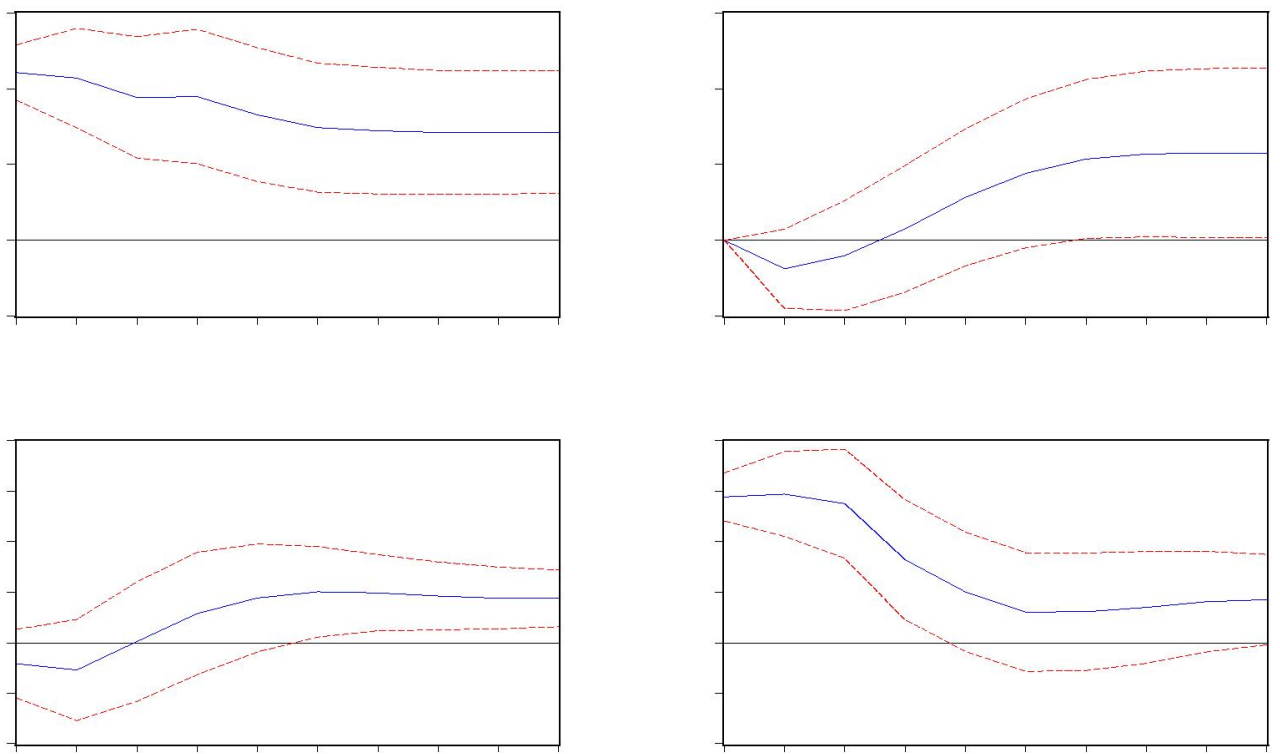

\section{Gambar 6. Respon inflasi terhadap shock output gap (OGKF)}




\section{Penaksiran Kesenjangan Output Indonesia \\ Priono}

Untuk melihat seberapa besar kontribusi masing-masing shocks dapat dilihat dari variance decomposition sebagaimana pada tabel berikut.

Tabel 5. Variance Decomposition dari Inflasi (OGHP)

\begin{tabular}{cccc}
\hline $\begin{array}{c}\text { Horison } \\
\text { (Kuartal) }\end{array}$ & LIHK & OGHP & Standar Error \\
\hline 1 & 100.0000 & 0.000000 & 0.011002 \\
2 & 98.72620 & 1.273801 & 0.015883 \\
4 & 98.73819 & 1.261805 & 0.022425 \\
8 & 95.37202 & 4.627980 & 0.030882 \\
10 & 95.26176 & 4.738241 & 0.034321 \\
\hline
\end{tabular}

Terlihat bahwa komposisi inflasi di Indonesia di kontribusi oleh inovasi dirinya sendiri, namun menurun dalam jangka panjang. Kemudian diikuti oleh pengaruh output gap yang semakin naik dalam jangka panjang begitu halnya dengan nilai standar error dalam jangka panjang yang mengalami peningkatan.

Tabel 6. Variance Decomposition dari Inflasi (OGKF)

\begin{tabular}{cccc}
\hline $\begin{array}{c}\text { Horison } \\
\text { (Kuartal) }\end{array}$ & LIHK & OGHP & Standar Error \\
\hline 1 & 100.0000 & 0.000000 & 0.011063 \\
2 & 98.54017 & 1.459826 & 0.015503 \\
4 & 98.78812 & 1.211876 & 0.020508 \\
8 & 87.25931 & 12.74069 & 0.027125 \\
10 & 82.29982 & 17.70018 & 0.030058 \\
\hline
\end{tabular}

Komposisi inflasi masih di kontribusi oleh inovasi dirinya sendiri, namun menurun dalam jangka panjang. Kemudian diikuti oleh pengaruh output gap yang semakin naik dalam jangka panjang begitu halnya dengan nilai standar error dalam jangka panjang yang mengalami peningkatan. Dibandingkan dengan metode Hodrick-Prescott, metode Kalman filter memiliki pengaruh output gap dalam jangka panjang lebih besar. 


\section{Journal of Indonesian Applied Economics \\ Vol. 2 No.1 Mei 2008, 90-101}

\section{E.KESIMPULANDANREKOMENDASI}

1. Penaksiran output potensial dengan menggunakan metode Kalman Filter menunjukkan pergerakan trend jangka panjang mendekati output aktual dibandingkan dengan metode Hodrick-Prescott filter

2. Pengaruh shock output gap terhadap pergerakan inflasi dengan metode Kalman Filter menunjukkan respon yang lebih lambat dibandingkan dengan metode Hodrick-Prescott filter. Dalam jangka panjang, kontribusi output gap terhadap inflasi dengan metode Kalman Filter lebih besar dibandingkan dengan metode Hodrick-Prescott filter

\section{DAFTAR PUSTAKA}

Bank Indonesia, (2003), "Bank Indonesia Bank Sentral Republik Indonesia: Tinjauan Kelembagaan, Kebijakan dan Organisasi", Pusat Pendidikan dan Studi Kebanksentralan (PPSK)

Bank of Japan, (2003), "The Output Gap and The Potential Growth Rate:Issues and Applications as Indicator for The Pressure on Price Change, Quarterly Bulletin, May

Blanchard, Olivier Jean dan Danny Quah, (1989), "The Dynamic Effect of Aggregate Demand and Supply Disturbances", The American Economic Review, Vol.79 No.4, September

Cerra, Valerie dan Sweta Chaman Saxena, (2000), "Alternative Methods of Estimating Potential Output and The Output Gap:An Application to Sweden”, IMF Working Paper WP/00/59, March

Claus, Iris, (1999), "Estimating Potential Output for New Zealand: A Structural VAR Approach", Discussion Paper DP2000/03, Reserve Bank of New Zealand, July

Claus, Iris, (2000), “Is The Output Gap A Useful Indicator Inflation?”, Discussion Paper DP2000/05, Reserve Bank of New Zealand

Claus, Iris, Paul Conway dan Alasdair Scott, (2000), "The Output Gap: Measurement, Comparisons and Asessment”, Researh Paper No.44, Reserve Bank of New Zealand

De Brouwer, Gordon, (1998), “Estimating Output Gaps”, Research Discussion Paper, Reserve Bank of Australia, August

De Serres, Alain, Alain Guay dan Pierre St-Amant, (1995), "Estimating and Projecting Potential Output Using Structural VAR Methodology: The Case of The Mexican Economy”, Working Paper, Bank of Canada, March

Enders, Walter, (1995), “Applied Econometric Time Series”, John Wiley\&Sons,Inc.

Froyen, Richard T., (2002), "Macroeconomics Theories and Policies", 7th ed., Prentice Hall

Gujarati, Damodar N., (2003), “Basic Econometrics”, the 4th eds., McGraw Hill, pp.275-276

Harris, Richard, (1995), “Cointegration Analysis in Econometric Modelling”, Prentice Hall

Joseph, Charles dan Anton H. Gunawan, (2000), "Monetary Policy and Inflation Targeting in Emerging Economies", Proceedings of an International Conference, Bank Indonesia dan International Monetary Fund, July

Mankiw,Gregory N., (2003), "Macroeconomics", the 5th ed., Worth Publisher

Razzak, W.A, (2002), "Monetary Policy and Forecasting Inflation With and Without The Output Gap”, Discussion Paper DP2002/03, Reserve Bank of New Zealand 


\section{Penaksiran Kesenjangan Output Indonesia \\ Priono}

Scott, Alasdair, (2000), "Stylized Facts From Output Gap Measures”, Discussion Paper DP2000/07, Reserve Bank of New Zealand

Shone, Ronald, (1989), "Open Economy Macro - Economics : Theory, Policy and Evidence", Harvester-Wheatsheaf, pp. 22-30

Solikin, (2003), "Kurva Phillips dan Perubahan Struktural di Indonesia", Kuliah Umum, 20 Desember, Magister Sains UGM 